\title{
Believe in Literature: Character Education for Indonesia's Youth
}

\author{
Muassomah $^{1, *}$, Irwan Abdullah $^{2}$, Istiadah $^{3}$, Anwar Mujahidin $^{4}$, Nurnaningsih Masnawi $^{5}$, Sohrah $^{6}$ \\ ${ }^{1}$ Department of Language and Arabic Literature, Faculty of Humanities, Universitas Islam Negeri Maulana Malik Ibrahim, Indonesia \\ ${ }^{2}$ Department of Anthropology, Faculty of Cultural Sciences, Universitas Gadjah Mada, Indonesia \\ ${ }^{3}$ Department of English, Faculty of Humanities, Universitas Islam Negeri Maulana Malik Ibrahim, Indonesia \\ ${ }^{4}$ Department of Quranic \& Exegesis Studies, Faculty of Ushuluddin, Institut Agama Islam Negeri, Indonesia \\ ${ }^{5}$ Department of Hadith, Faculty of Ushuluddin \& Philosophy, Universitas Islam Negeri Alauddin, Indonesia \\ ${ }^{6}$ Department of Shariah Economic Law, Faculty of Shariah and Law, Universitas Islam Negeri Alauddin, Indonesia
}

Received January 6, 2020; Revised April 27, 2020; Accepted May 13, 2020

Copyright $(2020$ by authors, all rights reserved. Authors agree that this article remains permanently open access under the terms of the Creative Commons Attribution License 4.0 International License

\begin{abstract}
Character education has become a significant challenge in Indonesia, as youths have become involved in all sorts of criminal and illicit acts, including casual sex, narcotics, brawls, street racing, and gambling. Even though character education is recognized as necessary for preparing the country's future generations, the current system has been incapable of resolving the issues facing Indonesia's youths or instilling them with desired character traits and values. This article examines literature's potential as an alternative approach and medium for character education. It provides a detailed map of how literary character education has been conducted, as well as how character traits and values have been identified and communicated by students. Data were collected by observing the learning process in a classroom and conducting interviews with teachers and students. Further observation was conducted to understand students' experiences with character education, both within and without the classroom. This study found that through the application of literature as a medium for and approach to character education, students' cognitive, affective, and psychomotor intelligences were improved. Literature contains specific messages and values that help students attain intellectual, emotional, and spiritual maturity. As such, it may be surmised that textual reading and analysis of literature, as a learning medium, can transfer desired values to students and enable them to contextualize said values. To complement the use of literature, this study recommends the development of alternative approaches to character education that make effective evaluation possible.
\end{abstract}

Keywords Character Education, Literature, Youth, Learning Method, Madrasah

\section{Introduction}

Education is facing ever more significant challenges as Indonesia's youth fall prey to immorality and decadence, even as the nation requires youths of proper quality to guarantee its advancement (Rindrayani, 2020). Teenagers violate moral norms, conduct criminal activities, sell drugs and pornographic films, practice free sex and prostitution, and even commit murder (Fauzan, 2019; Wulandari \& Hodriani, 2019). Given the necessity of preparing human resources that reflect the character of the Indonesian people, this identity crisis requires serious consideration. Despite the country's best efforts, education has been unable to shape new generations (Hasibuan, Syah, \& Marzuki, 2018). Teacher-oriented education, which is unidirectional and unilateral, has reduced students' interest in learning and limited their creativity (Borhan et al., 2020). Creating new creative spaces, or expanding available ones, will better enable students to produce original, product-oriented ideas; give them the ability to resolve practical issues; and open them to new experiences (Matraeva, 2020).

An alternative approach to character education-one that not only teaches students their ancestral values, but also prepares them for the future-is necessary. Unidirectional education, which relies on lectures and other teacher-oriented activities, is no longer capable of meeting educational needs (Kamaruddin, 2012). Student-oriented processes that enable youths to become accountable for their learning activities and actions are necessary; only then can students acquire the necessary competencies (Borhan et al., 2020). By actively seeking out and obtaining contextual knowledge based on their social experiences, students can better fulfill their needs. 
Literature has been found to have significant potential for involving students in the learning process (Zamroni, 2011).

Many studies have attempted to explore the issue of character education, focusing on the use of religious, cultural, and national values as elements of character-building (Ainiyah, 2013; Zuriah, 2014; Khotidjah \& Izzah, 2015; Sabunga et al. 2016; Mahardika, 2017: 18). These studies have suggested a range of media for character education, including not only schools (Rokhman et al., 2014; Ilma, 2015; Kurniawan, 2015; Rokhman, 2016) but also families (Roshida \& Haslinda, 2007; Purwaningsih, 2010; Hyoscyamina, 2011; Hasibuan, 2012; Subianto, 2013; Suarmini et al., 2016). Studies have also explored the influence of various academic disciplines on character education (Wening, 2012; Putri, 2013; Anshori, 2014; Dianti, 2016) certain disciplines have been found minimally effective, focusing more on students' cognitive achievements than their character development (Dianti, 2016; Abdullah et al., 2019). Few studies, however, have explored literature's ability to shape students' character.

It is believed that affective achievements are possible through literature, as the medium has significant potential to influence students' character (Zamroni, 2011; Wulandari, 2015). According to Wulandari, literature is central to character education because it explores the fundamental values of its society, thereby conveying necessary values to students and shaping their character. As a learning medium, literature can be used receptively and expressively as a means of character-building (Wulandari, 2015).

As a cultural product and emotional medium, literature offers an alternative means of shaping youths' character and honing their minds and morals. It has been used widely (albeit simply) for this purpose. For example, parents often read stories or tell tales to their children before bedtime. Through the characters in these works, they introduce their children to specific behaviors and identify desirable traits. The diversity of modern literature offers us numerous media that may be better suited for youths and older children.

Where earlier studies have focused on character education as part of formal school activities and lessons, identifying character as something simply received by students at certain times, this study explores the of literature as a model of character education at the senior high school-level, where students internalize values within the context of their empirical experiences. Given that it is student-oriented, rather than teacher-oriented, a literary approach is considered an effective means of imbuing youths with specific character traits and values. In such an approach, knowledge and values are not simply received by students, but discovered and identified through their reading activities.

\section{Literature Review}

According to the Great Dictionary of the Indonesian Language of the Language Center, 'character' refers to the behavioral, mental, and moral traits that distinguish one person from another. It is derived from the Greek word kharássō ('to mark'), and encompasses the application of certain values through one's behavior and activities (Fadjaray, 2018). Character must be distinguished from temperament, which refers predominantly to one's tendencies in responding to external and internal stimuli. Temperament is heavily informed by one's biopsychological conditions, by one's hormones, and as such cannot easily be changed. Meanwhile, character - known in Islam as rusyd - is shaped by one's life journey, particularly one's knowledge, experiences, and evaluations thereof. Character is shaped by, and informs, all human interactions. It constitutes not only a mental state, but is formed from mental, moral, and spiritual components (Anshori, 2014: 89).

Character-building is integrated into Indonesia's education system, under the belief that the Indonesian nation should be built upon its peoples' noble ancestral values. Education has played a central role in character building, given its strategic position and role (Ilma, 2015; Sudrajat, 2011; Sukitman, 2012; Supranoto, 2015; Sutyitno, 2012). Although character-building is also offered by informal and non-formal institutions, which work together with formal institutions to shape the character of the Indonesian people (Ilma, 2015), educational institutions have received the most attention as Indonesian society has deemed them ineffective. Recognizing that the country's youths are experiencing significant moral and identity crises, it is necessary to examine how character education can be conducted systematically and appropriately to achieve specific goals.

Evaluations of educational institutions have shown that these institutions have yet to perform optimally. Graduates lack the character and competencies that reflect national culture. The education system tends to emphasize the cognitive, with the affective being ignored-despite its necessity for social life (Sloan, 2020). Educational institutions' shortcomings are also evident in their curricula, which introduce specific character concepts and values but fail to integrate them into their learning processes (Sutiyono, 2015). Educational institutions have thus been unable to transform and improve the morals of Indonesian society, as required by Law No. 20 of 2003 regarding the National Education System.

Indonesians are experiencing a widespread character crisis, one that is marked by violations of legal, social, and religions norms. This character crisis is also a cultural crisis, one that could potentially erode the morals and dignity of the Indonesian people (Cahyadi, 2014; Hadisi, 2015). The illegal and immoral practices that are occurring in social and national life cannot be separated 
from shortcomings in character education. Bad governance, which can also be attributed to improper character education, has resulted in stagnancy, as has Indonesians' lack of the confidence necessary to compete at the global level.

Character education represents the accumulation of knowledge and wisdom necessary to create welfare and harmony, thereby ensuring the smooth functioning of society (Rokhman et al., 2014: 1163). It enables students to adopt specific traits and internalize particular values, which they reflect through their thoughts, emotions, and behaviors (Rawana et al., 2011: 140) According to Alexande (2001: 67), character education teaches students such values as accountability, responsibility, discipline, patience, and diligence. Families are at the frontlines in character education, and thus provide an effective means of conveying values and beliefs (Hyoscyamina, 2011; Purwaningsih, 2010; Roshida and Nik Haslinda, 2007; Suarmini et al., 2016; Subianto, 2013). Similarly, schools serve not only to transfer knowledge to students, but also to shape the attitudes, behaviors, character, and abilities of future generations (Rokhman, 2014: 1161). Social and religious institutions are similarly important in character education (Haningsih, 2008; Nurmalisa \& Adha, 2003).

\section{Method}

This article is based on research conducted at a senior high school-level madrasah (MA) in Malang, Indonesia. This madrasah incorporates the psychology of child development into its character-building activities, using literature as its main medium for character education; as such, students' character is not only shaped through local and national content. The MA has identified literature as an appropriate medium for character education, enabling it to avoid the common pitfalls of teacher-oriented character education (Rohinah, 2011: 11). Literature is not only incorporated into formal lessons and extracurricular activities, but also presented through 'words of wisdom' (mahfudhat) that are hung throughout the school. This is hoped to enable students to understand right and wrong while avoiding excessive routine and monotony.

Data were collected through observation and interviews over the course of five months. Observation was conducted participatively, within the classroom, and used to collect data on the teaching process in Class X. A total of 32 students were observed to assess their involvement in literature-based education. At the same time, the teacher was observed both in the teaching and learning processes in the classroom and in school activities outside the classroom. Five teachers were then selected for in-depth interviews, including other related subject teachers. Observations of teachers and students were used specifically to collect data about: (a) teachers' activities and behaviors during the learning process; (b) students' activities and behaviors during the learning process; (c) students' group activities during the learning process; (d) teachers' roles as motivators and facilitators in character education; (e) students' involvement in the exploration of literary texts, particularly their identification of said texts' values and messages; and (f) the products and works hung on the classroom walls.

Interviews were aimed at obtaining information and clarification regarding literature as a medium and as a method for conveying specific values to students. Recognizing their authority in the classroom as well as their planning of learning activities, teachers were the key informants. During interviews, teachers were asked about the methods and strategies used to incorporate literary texts and messages into character education. Data regarding the teacher's textual and contextual evaluations of students' internalization of desired character traits were also obtained through interviews. At the same time, a number of selected students were interviewed as secondary informants to focus on their experiences reading prose (The Tale of Bayan Budiman) and poetry, their identification of said texts' messages, and their diverse and complex experiences applying these values within their social lives.

Data collected through observation and interviews were analyzed descriptively and interpretively through three stages: (a) data reduction, looking at the relevance of the data to the research questions and objectives concerning the process of applying a literature-based learning model; (b) descriptive data presentation, based on three relevant aspects, namely materials used, student involvement, and teachers' role; and (c) discussion and conclusion of field findings, through which data were placed within the context of previous studies and community needs. Besides interpreting and giving meaning to the data and information, creative and innovative reflection was also used to better understand the results.

\section{Results}

\subsection{Literary Material used at the MA}

Literature, aside from being taught as a compulsory subject to all students (from Class X through Class XII), is also used to convey specific messages and character values to students. Two main types of literary material are provided to students: oral literature and written literature (prose and poetry).

Although these materials will be described below, it is first necessary to define oral literature and written literature as provided to MA students. Oral literature refers to the literary and cultural expressions that are passed from generation to generation through oral means. Written literature, meanwhile, has a more honored position in society and culture, being identified as 
reflecting a more developed and advanced civilization (and, thus, a cornerstone of modernity). Written literature traces its roots to the steles and inscriptions through which people first put their language into writing.

Oral literature has seven key characteristics: (a) it is transmitted from generation to generation orally, from mouth to mouth; (b) it emerges in illiterate rural societies; (c) it represents the culture of its source society; (d) it has poetic tendencies; (e) it can be found in various versions; (f) it prioritizes imagination over facts and truth; and (g) it uses everyday spoken language. Written literature, meanwhile, is modern and adaptable, being informed by technological and cultural advancements. As it transforms, literature seeks to hone and advance itself, to improve itself over other fields.

Second, it is also necessary to define prose and poetry as provided to students. Prose refers to a free form of writing, one that is not confined by specific conventions of rhyme, rhythm, diction, and drama. Prose is commonly divided into fiction and non-fiction, with the former referring to imaginative tales that are not necessarily based in reality and the latter referring to more truthful - or even academic-works. Prose is also commonly divided into classical and modern prose; the former includes fairy tales, epics, legends, fables, and sagas, while the latter includes short stories, novels, and novellas. All types of prose have both intrinsic and extrinsic elements. Intrinsic elements include theme, plot, characters, characterization, setting, perspective, and style, while extrinsic elements include lessons, messages, and values (which may include piety, honesty, dedication, sincerity, patience, obeisance, and diligence).

At the MA, literature classes during odd semesters focus on classical prose. Only one form of classical prose is used, with the expectation that students will obtain a detailed and comprehensive understanding of the work's intrinsic and extrinsic values. For this, the teacher chose hikayat, a traditional Malay form of prose that commonly contains stories, tales, laws, imaginative histories, and religious teachings. In general, such hikayat tell about the extraordinary and heroic deeds of individuals, and are replete with mysticism, magic, and miracles.

In Class X, students were introduced to The Tale of Bayan Budiman (Hikayat Bayan Budiman). This tale was used in class for reading and discussion, and students were introduced to its intrinsic and extrinsic elements.

Conversely, Class X students focus on poetry during even semesters; poetry is presented to students after prose as it is considered more difficult. Poetry may be defined as an emotional linguistic expression that prioritizes its aesthetic elements. It consists of two elements, namely physical and mental. The former refers to its form, including its diction, concrete language, figurative language, rhyme, rhythm, typography, and presentation, while the latter refers to its textual discourse, particularly the significance-sense, feeling, tone, and intention - understood by readers.

At the MA, Class X students were introduced to the works of Chairil Anwar and Agus Mus, two Indonesian poets whose poems are identified as promoting character education. Students were introduced to both the physical and mental aspects of the poems, and asked to identify the character values conveyed through these works. The works of Chairil Anwar were selected to represent early Indonesian literature, and tend to convey such values as patriotism, friendship, and a willingness to fight for a free Indonesia. Meanwhile, the works of Gus Mus were chosen to represent contemporary Indonesian literature, and to present students with religious and cultural messages. The MA and its teachers hope that, through the works of these poets, students will internalize particular values and character traits.

\subsection{Involvement of Students in Literature-based Character Education}

Works of literature are important in Indonesian society, including amongst Indonesian youths, because they not only provide entertainment but also convey specific values and ideas. High school-level students should be directly involved in their character education, including through literature, as this ensures that they internalize specific moral values and practice said values voluntarily. At the MA, the process involves reading literary works, retelling said literary works in front of the class, and applying these works' values within their everyday lives. These stages are described in detail below.

First, the reading of literary works begins with students reading and studying the chosen work. For example, during the odd semester, students studied The Tale of Bayan Budiman. Through its eight sub-themes, the hikayat contrasts the moral and the immoral, the admirable and the deplorable. Each sub-theme was discussed individually over the course of the semester. Students were provided with printouts of the hikayat and asked to read them in their entirety before coming to class. Every time these materials were discussed, students were expected to have sufficient information and broad knowledge about the relevant sub-theme.

A similar approach was used when discussing poetry. Students were asked to search for specific works by Chairil Anwar and Gus Mus, print these works, and read them. Although students were informed which works they should read, they were not told which themes to identify. Students thus identified different themes within the same work during their reading. In class, students were guided in identifying the physical and mental elements in the poems that they read.

During the second stage, students retold the literary work to their peers. In the odd semester, students were asked to identify the intrinsic elements of The Tale of Bayan Budiman-its theme, plot, characters, 
characterization, setting, perspective, and style. Under the guidance of the teacher, these intrinsic elements were then discussed within the context of a specific sub-theme. Students were also expected to identify the extrinsic elements of the literary work, particularly its values and messages. They were divided into groups, then asked to discuss the literary work and identify the character values contained therein. Each group presented its findings to the class, again under the guidance of the teacher. When retelling the hikayat, students were asked to use their own language; however, they were reminded to focus on the meaning of the text.

When discussing poetry, students were also divided into small groups and asked to identify the poems' physical elements. These groups similarly discussed the mental elements of the poems, as well as the moral values they conveyed. Each group chose a representative to present its findings to the class. Students were also asked to read these poems to their peers, with a focus on aesthetic quality (particularly rhythm).

Third, students were asked to apply the messages and values of the literary work. In the odd semester, this began with discussion of how students could apply the hikayat and its message in their everyday lives, including at school and in society. Students were asked to develop an understanding of the aesthetic and moral values presented through The Tale of Bayan Budiman, and to position them vis-à-vis the values they practiced in their everyday lives. As part of their analysis, students were asked to provide examples of how the values contained within the hikayat harmonized with those of their society. In brief, students were expected to obtain an understanding of the prose and its essential values.

Likewise, when discussing poetry, students were divided into groups and asked to discuss the literary works, not only identifying the poems' physical elements, but also exploring their mental components. To identify the mental elements of these works, students required serious consideration and comprehensive analysis. Collaboration was thus necessary, with students expressing their individual opinions and ideas to collaboratively identify the works' sense, feeling, tone, and intention.

\subsection{Role of Teachers in Literature-based Character Education}

Teachers not only serve as educators and transfer knowledge to students, but also act as role models whose every deed and word is taken as an example. They thus have an important role in conveying specific character traits and values to students. In a student-oriented process, teachers help students understand the moral messages of literary works through three activities: identifying the literary work/compilation, presenting the message of the literary work to students, and evaluating students' character development and abilities. These activities are discussed below.

First, to identify appropriate literary works/compilations, teachers require particular resource materials. In Class X of the MA, the teacher referred to a handbook written by Titik Hersiati (a professor of Indonesian literature at Malang State University, Indonesia). This handbook presents literary theories and concepts, including definitions of classical literature, modern literature, and literary elements; it also includes examples of literary works. The teacher also compiled a number of works dealing with The Tale of Bayan Budiman, including retellings of the hikayat. Similarly, the teacher consulted a number of anthologies to identify early and contemporary Indonesian poems that were appropriate for students. Supporting these efforts, the school's library offers a number of literary works (novels, poems, short stories, etc.) that can also be consulted or used as examples during the learning process.

Second, to convey the message of the literary work, the teacher read the chosen work (the hikayat or poem) at home, outside of school hours. This ensured that, during class, the teacher did not need to read the work, but was prepared to discuss its content and context immediately with students. The teacher identified the character values that students should internalize and apply in their everyday lives, described the message of the literary text, and positioned it within the context of students' everyday lives.

Discussion of the values contained within the literary text did not only involve the teacher and students; discussion also occurred amongst students, who were divided into eight groups by the teacher. Each group discussed the same sub-theme, and was expected to understand the work's message and values within a specific context as well as provide examples of behaviors that reflect and/or deviate from religious and cultural norms. In this, the teacher served as a facilitator and motivator. In the former role, the teacher eased the learning process by asking students questions that could be answered by identifying the character values within the text. In the latter role, meanwhile, the teacher provided a personal example of how specific values - such as love and concern - could be implemented. These values were incorporated into the teacher's everyday behaviors and attitudes, thereby providing an inspiration to students. The teacher also used specific tricks and methods to stimulate students' love of learning and inspire them to study on their own.

Third, the teacher employed the "MoU method" to evaluate students' ability to understand the literary work and the values it contained, as well as their ability to practice said values in their everyday lives. During the first class, the teacher and students signed a memorandum of understanding (MoU) that identified literature as a project-based class, with students receiving a reward if they followed agreed-upon stages and met agreed-upon 
benchmarks. For example, of the 32 students in Class X, between 15 and 20 were capable of retelling and analyzing The Tale of Bayan Budiman. These students were not only able to retell the hikayat orally, but also create a portfolio through which they retold it as a short story in their own words. Selected short stories were edited for legibility, then compiled and published as an anthology. This program has become a central part of literature education at the MA, and students have been able to internalize the desirable values and character traits presented through the literary work.

A different MoU was used for poetry. Students' understanding of poems was evaluated through their musicalization of these works, with performances being held outdoors (i.e. on the classroom terrace or in the schoolyard). During their first class, students were informed of the system through which poetry was taught, and asked if any were skilled musicians; usually, at least one student can play an instrument. From the first class, students were divided into eight groups, with the expectation that they could work together to adapt the poem into a song. For their performance, students were allowed to either adapt the works of others or write their own.

The teacher employed different approaches to evaluate students' understanding of literary works. For oral evaluation, students were asked to retell the hikayat they had read or to perform a poem. For written evaluation, students were tested and given questions regarding the materials conveyed by the teacher. To evaluate the extent to which students internalized the desired character traits and values, the teacher observed how they incorporated these traits and values in their everyday lives. Students also discussed their personal experiences, as well as what they observed at school, at home, and elsewhere. Students were thus expected to identify the desirable traits, internalize them, and avoid undesirable traits. The success of character education was also evaluated based on students' interactions, including their collaboration, mutual respect, and openness to others' ideas during group sessions.

\section{Discussion and Conclusions}

From the use of literature at the observed MA, a different approach to character education (albeit one with the same goal) has been identified. Through this process, students have been able to identify and internalize desired values and character traits. At this MA, literature- both prose and poetry-has been used successfully as a resource in the learning process. It has provided an alternative medium for learning, one that has broken the tedium of the top-down process. This use of literature reflects the need for reducing the use of lectures and other unidirectional approaches to learning. As argued by
Nurseto:

".. in today's learning environment, which emphasizes ... active processes and learning, learning media has taken ... a more important role. Regarding literature as a learning medium, several points may be emphasized: it provides a more effective learning medium, accelerates the learning process, improves the quality of the learning process, concretizes the abstract, and reduces the influence of verbalism" (Nurseto, 2012).

Literature can entice students to involve themselves in the character education process, as it provides them with a space to become involved in the learning process and reduces the prevalence of lectures and other unidirectional approaches.

The learning process at the studied MA has shown three important phenomena. First, a paradigm shift is currently occurring in Indonesia's education system (Samad \& Wekke, 2019). This study has shown that a literary approach can address the need for a creative learning process that entices students and instills them with desired values. In other words, literature can provide a solution to the critical issue of character education, particularly its failure to meet students' needs (Prihartoyo \& Dwiningrum, 2014; Yusuf, 2014). Teachers' ability to use a range of approaches in communicating materials will determine the success of character education (Hasibuan, Syah, and Marzuki, 2018; Rindrayani, 2020). This will also inform students' interest in lessons, as well as the extent to which they internalize what they learn.

Second, this study's focus on the use of literature has distinguished it from previous studies, which have tended to focus on literary works' aesthetic and intrinsic values. Generally, literature lessons are oriented towards teachers, focusing on their analyses and explanations (Nugrahani, 2012). This study, meanwhile, has examined a case in which literature has been used as a medium for conveying and promoting the internalization of specific values. Students are involved directly, being asked to identify the implicit messages and values of literary works and then contextualize these messages and values. In other words, students are expected to identify specific values, embody them, and incorporate them in their everyday lives. This study has supported the argument that literature offers a good medium for ensuring that students have the desired competencies (Keshavarzi, 2012). As in the United States, literature can be used to transfer core values to children and youths during their formal and informal educational (Edgington, 2002).

This finding also supports the argument that literature offers an important medium for character education, as it conveys substantial life values across space and over time (Supriyono, Wardani, \& Saddhono, 2018). It plays an integral role in creating harmony and balance (Wulandari, 2015). Literature is the best medium for ensuring that 
students internalize specific messages and values, improving not only their intellectual capabilities but also their emotional maturity and spiritual piety (Zamroni, 2011). This reflects Almerico's argument that literature must be incorporated into curricula, as it offers a more effective means of conveying desired values to students and helping them meaningfully and substantially develop themselves (Almerico, 2014). In character education, cultural values and symbols are particularly effective (Wardani \& Widiyastuti, 2013). Even as they are written by individual authors and poets, prose and poetry are culturally produced. As such, they not only convey moral and spiritual messages, but also instill students with a love for their culture.

Third, this study of character education reaffirms that the current education system is isolated from the social environment (Abdullah et al., 2019). Although students are capable of identifying desirable values and understanding the messages of prose and poetry, there is limited space for the text and context to interact. As such, schools have difficulty ensuring that students - who often come from diverse cultural backgrounds-incorporate these values within their social lives and practice them in their social interactions. As shown by Rindrayani (2020), character education must be more than curricular: it must connect students with those around them (Rindrayani, 2020). Indonesia's current system, lacking this capacity, has been unable to develop students' affective and psychomotor skills.

Literature is a useful medium for character education and a product of contemplation and imagination. It conveys specific values and ethics to audiences. As such, this study recommends broadening the scope of the literature used in character education to include more than prose and poetry. By doing so, students will be exposed to a greater variety of moral and social values, which they can internalize and practice both at school and elsewhere. At the same time, this research is limited to the experience of one school. As such, it cannot provide a comprehensive or comparative picture. Future research must not only include several schools, but also accommodate different types of schools, both private and public, religious and secular. For this reason, comparative research that takes into account differences in curricular orientation and covers diverse school typologies is necessary.

\section{REFERENCES}

[1] Abdullah, I., Hudayana, B., Kutanegara, P.M., Indiyanto, A. (2019). Beyond school reach: Character education in three schools in Yogyakarta, Indonesia. Journal of Educational and Social Research, 9(3), 145-159. doi: 10.2478/jesr-2019-0032

[2] Adhuri, D. (2013). Marine tenure and precedence contestation: A village destroyed. In Selling the sea, fishing for power: A study of conflict over marine tenure in Kei Islands, Eastern Indonesia (pp. 163-186). ANU Press. Retrieved from www.jstor.org/stable/j.ctt2jbkt1.20.

[3] Ainiyah, N. (2013). Pembentukan karakter melalui pendidikan agama Islam (Character building through Islamic religious education). Jurnal Al-Ulum, 13(1), 2538.

[4] Alexander, C. M. (2001). Character development: A value-added concept. Seminars in Orthodontics, 7(2), 6773. doi: $10.1053 /$ sodo. 2001.23539

[5] Almerico, G. M. (2014). Building character through literacy with children's literature. Research in Higher Education Journal, 26, 1-13.

[6] Anshori, S. (2014). Kontribusi ilmu pengetahuan sosial dalam pendidikan karakter (The contribution of social science in character education). Jurnal Edueksos, 3(2).

[7] Arjanggi, R. (2012). Pendidikan karakter terintegrasi dalam pembelajaran di perguruan tinggi (Integrated character education in learning in tertiary institutions), in Prosiding Seminar Nasional Psikologi Islami.

[8] Borhan, M.T., Saleh, S., Li, A.T.S., Ong, E.T. (2020) Readiness in implementing student-centred learning (SCL): An insight to developing a problem-based learning (PBL) module. Universal Journal of Educational Research, 8(1): 119-126. http://www.hrpub.org DOI: 10.13189/ujer.2020.080114

[9] Cahyadi, A. (2014). Menguatkan Indonesia: Revitalisasi pembelajaran pendidikan karakter (Strengthening Indonesia: Revitalizing character education learning). Analisis: Jurnal Studi Keislaman, 14(2), 357-374.

[10] Dianti, P. (2016). Integrasi pendidikan karakter dalam pembelajaran pendidikan kewarganegaraan untuk mengembangkan karakter siswa (Integration of character education in citizenship education learning to develop student character). Jurnal Pendidikan Ilmu Sosial. https://doi.org/10.17509/jpis.v23i1.2062

[11] Edgington, W. D. (2002). To promote character education, use literature for children and adolescents. The Social Studies, 93(3), 113-116. https://doi.org/10.1080/00377990209599893

[12] Fadjaray, S. (2018). Character building strategies: bercocok tanam karakter di kebun sanubari anak (Character building strategy: Planting character in children heart). Sidoarjo: Rahmat Media Press.

[13] Fauzan, I. (2019). Konsep bimbingan dan konseling dalam mengatasi kenakalan siswa: Studi kasus di MTS Al-Gozali kecamatan Jatibarang. (The concept of guidance and counseling in overcoming student delinquency: A case study in MTS Al-Gozali Jatibarang Subdistrict). Al-Afkar, Journal for Islamic Studies, 4(1), 125-140. https://doi.org/10.31943/afkar_journal.v4i1.63

[14] Hadisi, L. (2015). Pendidikan karakter pada anak usia dini (Character education in early childhood). Al-Ta'dib: Jurnal Kajian Ilmu Kependidikan, 8(2), doi: http://dx.doi.org/10.31332/atdb.v8i2.410

[15] Haningsih, S. (2000). Peran strategis pesantren, madrasah dan sekolah Islam di Indonesia (The strategic role of pesantren, madrasa and Islamic schools in Indonesia). El Tarbawi, 1(1), 27-39. Retrieved from 
http://www.jurnal.uii. article/view/186

ac.id/index.php/Tarbawi/

[16] Hasibuan, A. A., Syah, D., \& Marzuki, M. (2018). Manajemen pendidikan karakter di SMA (Management of character education in high school). Tarbawi: Jurnal Keilmuan Manajemen Pendidikan. https://doi.org/10.32678/tarbawi.v4i02.1230

[17] Hasibuan, E. J. (2012). Peranan komunikasi dalam keluarga terhadap pembentukan jatidiri remaja (The role of communication in the family to develop adolescent identity), Perspektif, 1(2), doi: http://dx.doi.org/10.31289/perspektif.v1i2.91

[18] Hidayatullah, R. (2019). Peran lingkungan madrasah dalam mengatasi kenakalan siswa (The role of the madrasa environment in overcoming student delinquency). Irfani, $15(2)$ 87-94. http://journal.iaingorontalo.ac.id/index.php/ir

[19] Hyoscyamina, D. E. (2011). Peran keluarga dalam membangun karakter anak (The role of the family in building children's character). Jurnal Psikologi Undip, 10(2), 144-152.

[20] Ilma, N. (2015). Peran pendidikan sebagai moral utama membangun karakter bangsa (The role of education as the main morality in building nation's character). Manajemen Pendidikan Islam, 3, 82-87.

[21] Kamaruddin, S. A. (2012). Character education and student social behavior. 6, 223-230.

[22] Keshavarzi, A. (2012). Use of literature in teaching English, Procedia - Social and Behavioral Sciences. doi: 10.1016/j.sbspro.2012.05.159.

[23] Khodidjah, S. \& Izzah, H. (2015). Islamic habituation sebagai upaya pembentukan karakter anak usia dini (Islamic habituation as an effort to form the character of early childhood). PG-PAUD, 2(2), 125-132.

[24] Mahardika, A. (2017). Penanaman karakter bangsa berbasis kearifan lokal di sekolah (Cultivating the character of the nation based on local wisdom in schools). Jurnal Pendidikan Kewarganegaraan, 7(2), 16-27.

[25] Matraeva1, A. D., Rybakova1, M.V., Vinichenko, M.V., Oseev, A.A., \& Ljapunova, N.V. (2020). Development of creativity of students in higher educational institutions: assessment of students and experts. Universal Journal of Educational Research, 8(1): 8-16, DOI: 10.13189/ujer.2020.080102

[26] Munadi, A. (2015). Gagasan nilai-nilai pendidikan karakter Tgh. M. Zainuddin Abdul Madjid (The idea of the character education values of Tgh. M. Zainuddin Abdul Madjid), El-Hikam, 8 (2).

[27] Nugrahani, F. (2012). Reaktualisasi tembang dolanan Jawa dalam rangka pembentukan karakter bangsa: Kajian semiotik (Reactualization of Javanese Dolanan song in the context of nation's character building: A semiotic study). Kajian Linguistik dan Sastra, 24(1), 58-68. .

[28] Nurmalisa, Y. \& Adha, M.M. (2003). Peran lembaga sosial terhadap pembinaan moral remaja di sekolah menengah atas (The role of social institutions in the development of adolescents moral in high school). Jurnal Ilmiah Pendidikan Pancasila dan Kewarganegaraan, 1(1), 1-6.

[29] Nurseto, T. (2012). Membuat Media Pembelajaran yang
Menarik (Making Learning Media Interesting). Jurnal Ekonomi dan Pendidikan. doi: 10.21831/jep.v8i1.706

[30] Prihartoyo, Y. R. \& Dwiningrum, S. I. A. (2014). Manajemen pendidikan karakter di SMA De Britto Yogyakarta (Management of character education at De Britto Yogyakarta High School). Jurnal Akuntabilitas Manajemen Pendidikan. doi: 10.21831/amp.v2i1.2415.

[31] Purwaningsih, E. (2010). Keluarga dalam mewujudkan pendidikan nilai sebagai upaya mengatasi degradasi nilai moral (Families in realizing value education as an effort to overcome the degradation of moral values). Jurnal Pendidikan Sosiologi dan Humaniora, 1(1), 43-55.

[32] Putri, N. A. (2013). Penanaman nilai-nilai pendididkan karakter melalui mata pelajaran sosiologi (Instilling the values of character education through sociology subjects). Komunitas: International Journal of Indonesian Society and Culture. doi: 10.15294/komunitas.v3i2.2317.

[33] Rawana, J., Franks, J., Brownlee, K., Rawana, E. \& Neckoway, R. (2011). The application of a strength-based approach of students' behaviours to the development of a character education curriculum for elementary and secondary schools. The Journal of Educational Thought (JET) / Revue De La Pensée Éducative, 45(2), 127-144. Retrieved from http://www.jstor.org/stable/23767076.

[34] Rindrayani, S. R. (2020). The implementation of character education in Indonesia high school curriculum program. Universal Journal of Educational Research, 8(1): 304-312, doi: 10.13189/ujer.2020.080137

[35] Rohinah. (2014). Model pembelajaran pendidikan agama Islam (PAI) berbasis multikultural sebagai upaya penanaman karakter pada siswa sekolah dasar Sanggar Anak Alama (Salam) Nitiprayan Bantul Yogyakarta (The learning model of Islamic education (PAI) based on multiculturalism as an effort of instilling character among elementary school students at Sanggar Anak Alama (Salam) Nitiprayan Bantul, Yogyakarta). Pendidikan Agama Islam, 11(2), 269-288.

[36] Rokhman, F., Hum, M., Syaifudin, A. \& Yuliati. (2014). Character education for golden generation 2045 (National Character Building for Indonesian Golden Years). Procedia - Social and Behavioral Sciences, 141, 11611165. doi: 10.1016/j.sbspro.2014.05.197.

[37] Sabunga, B., Budimansyah, D. \& Sauri, S. (2016). Nilai-nilai karakter dalam pertunjukkan wayang Golek Purwa (Character values in the Golek Purwa puppet show). Jurnal Sosioreligi, 14(1), 1-13.

[38] Shamad, A. \& Wekke, I. S. (2019). Lecturers' participation in applying blended learning in Islamic higher education in Indonesia. Universal Journal of Educational Research, 7(12): 2604-2608, doi: 10.13189/ujer.2019.071207

[39] Sloan, J. (2020). Learning to think strategically. New York: Routledge.

[40] Suarmini, N.W., Rai, N.G.M. \& Marsudi, M. (2016). Karakter anak dalam keluarga sebagai ketahanan sosial budaya bangsa (The character of children in the family as a social and cultural resilience of the nation). Jurnal Sosial Humaniora, 9(1), 78. doi: 10.12962/j24433527.v9i1.1280.

[41] Subianto, J. (2013). Peran keluarga, sekolah, dan masyarakat dalam pembentukan karakter berkualitas (The role of families, schools, and communities in the formation 
of quality characters). Edukasia: Jurnal Penelitian Pendidikan Islam, 8(2), 331-354.

[42] Sudrajat, A. (2011). Mengapa pendidikan karakter? (Why character education?) Jurnal Pendidikan Karakter, 1(1), 47-58. doi: 10.21831/jpk.v1i1.1316

[43] Sukitman, T. (2012). Pendidikan karakter berwawasan sosiokultural (Socio-cultural based character education). Jurnal Pelopor Pendidikan, 3(1), 11-20.

[44] Supranoto, H. (2015). Implementasi pendidikan karakter bangsa dalam pembelajaran SMA (The implementation of national character education in high school learning). Promosi (Jurnal Pendidikan Ekonomi), 3(1). doi: $10.24127 /$ ja.v3i1.141.

[45] Supriyono, S., Wardani, N. E., \& Saddhono, K. (2018). Nilai pendidikan karakter sajak "Bulan Ruwah" karya Subagio Sastrowardoyo dalam pembelajaran sastra (The value of "Bulan Ruwah" rhyme character education by Subagio Sastrowardoyo in literary learning). Scholaria: Jurnal Pendidikan dan Kebudayaan, 8(2), 120-131. doi: 10.24246/j.js.2018.v8.i2.p120-131

[46] Suriyanti. (2016). Pembelajaran pendidikan agama Islam (PAI) dalam membentuk karakter Islami (Akhlak Mahmudah) di SMA Negeri 9 Bandar Lampung (Islamic religious education (PAI) learning in the formation of Islamic character [Akhlak Mahmudah] at Senior High School 9 Bandar Lampung). Thesis. Lampung: Raden Intan State Islamic University.

[47] Susiatik, T. (2013). Pengaruh pembelajaran PKn terhadap pembentukan karakter siswa (The effect of civics learning on the formation of student character). Majalah Ilmiah Pawiyatan, 20(4).

[48] Sutiyono. (2015). Penerapan pendidikan budi pekerti sebagai pembentukan karakter siswa di sekolah: sebuah fenomena dan realitas (Application of character education as the formation of student character in schools: a phenomenon and reality). Jurnal Pendidikan Karakter, 3, 309-320.

[49] Sutyitno, I. (2012). Pengembangan pendidikan karakter dan budaya bangsa berwawasan kearifan local (Development of character and culture based on local wisdom). Jurnal Pendidikan Karakter, 2(1), 1-13.

[50] Wardani, N. E., \& Widiyastuti, E. (2013). Mapping wayang traditional theatre as a form of local wisdom of Surakarta Indonesia. Asian Journal of Social Sciences \& Humanities, 2(2). Retrieved from www.ajssh.leena-luna.co.jp

[51] Wening, S. (2012). The nation's character building through value education. Jurnal Pendidikan Karakter, 2(1), 55-66.

[52] Wulandari, D. O., \& Hodriani, H. (2019). Peran guru pendidikan kewarganegaraan dalam mencegah kenakalan remaja di sekolah (The role of the civic education teacher in preventing juvenile delinquency in schools). Journal of Education, Humaniora and Social Sciences (JEHSS), 1(3), 139-147. doi: 10.34007/jehss.v1i3.28

[53] Wulandari, R. A. (2015). Sastra dalam pembentukan karakter siswa (Literature in the formation of student characters). Jurnal Edukasi Kultura: Jurnal Bahasa, Sastra dan Budaya, 1(2), doi: 10.24114/kultura.v1i2.5181

[54] Yusuf, M. (2014). Pendidikan karakter berbasis Qurani dan kearifan local (Quranic-based character education and local wisdom), KARSA: Journal of Social and Islamic Culture, 22(1), 53-66.

[55] Zamroni. (2011). Bahasa dan sastra Indonesia sebagai wahana pendidikan karakter (Indonesian language and literature as a vehicle for character education). In Zamroni (ed.), Pendidikan karakter dalam perspektif teori dan praktik (Character education in theoy and practice). Yogyakarta: UNY Press.

[56] Zuriah, N. (2014). Analisis teoritik tentang etnopedagogi pendidikan kewarganegaraan sebagai wahana pendidikan budaya dan karakter bangsa di perguruan tinggi (Theoretical analysis of the ethnopedagogy of civic education as a vehicle for cultural and national character education in tertiary institutions). Sosiohumanika: Jurnal Pendidikan Sosial dan Kemanusiaan, 7(2), 175-188. 